\title{
Numerical modelling of geocell reinforced slope by use of plastic bottle waste
}

\author{
Afif Agri Diansyah, Fikri Faris* , Ahmad Rifa'i, and Roberth Evander Meidudga \\ Department of Civil and Environmental Engineering, Universitas Gadjah Mada, 55281, Yogyakarta, Indonesia
}

\begin{abstract}
Nowadays, waste management should be one of the focuses in controlling a healthy and sustainable environment. It is undeniable that plastic bottle waste has covered the earth's surface. One of the solutions to reduce the polluting impact is to use it as a geocell in the geotechnical field. The previous researchers more study about slope reinforcement using fabricated geocell. In this study, geocell is made by utilizing plastic bottle waste. Slope stabilization using geocell is a kind of internal stabilization. Other kinds of slope stabilization, such as using sheet piles and gravity walls, are external stabilization. The purpose of this study is to obtain an overview of the effect of the geocell reinforced slope. From experimental studies using plate load test, results obtained that geocell reinforce soil can increase the bearing capacity of the soil. Numerical modelling uses PLAXIS 2D modelled geocell reinforce slope as a slab that can spread the load widely over the reinforced area, also known as beam model. Young's modulus of geocell-soil composite is obtained from experimental studies, empirical equation and validated using axisymmetry in PLAXIS 2D. The results of this study, generally geocell reinforce slope can restrain the slope from failure deformation by redistributing the loads in a large area. The significant effect is shown in sandy soil with a high improvement factor $(I F)$, different to the reinforcement in clayey soil with a low improvement factor $(I F)$. It implies that plastic bottle waste can be used as a geocell which can increase its economic value. Since it is applicable, it can reduce the pollution caused by plastic bottle waste.
\end{abstract}

\section{Introduction}

Plastic waste became a severe problem faced by developing countries such as Indonesia. One type of plastic waste found in daily life is plastic bottles in several forms of its function, primarily as a beverage package. The most material commonly used is polyethylene terephthalate $(P E T)$. Hence it is solid waste, it takes a very long time to decompose. The needed time to naturally decompose is between $100-400$ years [1]. The potential pollution to the environment and natural disasters caused by this kind of waste is hazardous. It has contributed to global warming, floods, water pollution and many others. Therefore, this problem requires many solutions to minimize the potency and impact of the natural disasters caused by plastic bottle waste. On the other side, some failures in construction occur due to neglecting geotechnical aspects. Such failures are subsidence of foundation, railroad damage, failure of embankments, slope and others. Based on the environmental and geotechnical aspects above, this research utilizes PET into geocell used for soil reinforcement applied in various types of reinforcement. Geocell is a term of geosynthetics type. It has a different shape from other geosynthetics such as geogrid, geoweb, geomesh, etc. Geocell has a 3-D shape and resembles a honeycomb. The Confinement system provided by each cell to the soil inside forms a composite that produces a higher strength than ordinary soil (without geocell) [2]. Geocell can consist of various types and materials. It, which come from fabricating, have a standardized technical characteristic. Hand-made geocell can also use fabricated material such as geogrids which are then shaped into geocell by some manual process. Although plastic bottles are factory-made, the tensile strength of these plastic bottles can vary. Geosynthetics soil reinforcement became one of the solutions to increase soil strength which generally the problem was the bearing capacity or stability [3].

Geocell were first developed as soil reinforcement by the U.S army engineering corps to stabilize sand quickly [4]. Soil reinforcement is often considered a common problem, but the failure impact can take a high cost to rehabilitate or reconstruct. Soil reinforcement certainly requires additional costs and time, but the benefit obtained can extend life service and reduce maintenance costs. Currently, geocell has been widely used in geotechnical fields. It also can be applied to various soil types for embankment, retaining walls, railroad foundation, slope reinforcement from slide and erosion. The advantages of using geocell are fast processing time, low costs and being environmentally friendly.

\footnotetext{
${ }^{*}$ Corresponding author: fikri.faris@ugm.ac.id
} 
Previous researchers have carried out some experimental studies to study the effect of using geocell as soil reinforcement. However, in practice, it does not rely solely on experimental studies to design and analyze the geocell reinforcement, let alone on complex geometries. Hence experimental studies take quite a long time, and a numerical approach is required to simplify design and analysis in a fairly short time [5]. Numerical modelling of geocell as the original form indeed a quite difficult way cause the honeycomb shape has a complex geometry and the geocell thin sheet becomes an obstacle to modelled the structure. Another approach to model geocell numerically is with equivalent composites, where the geocell-soil layer can be modelled as a slab with stiffness parameters [6-9,5]. A numerical model of geocell reinforcement can also be modelled in 2-D, which representing the 3-D conditions. [10] used a 2-D model to design embankment with geocell based on laboratory studies. According to the literature study above, geocell reinforcement is able to increase the bearing capacity and reduce subsidence. In terms of using plastic bottle waste as geocell reinforcement, very few related reports are published, specifically on its application as slope reinforcement. [11] reported that geocell-soil reinforcement can behave as a retaining wall and strengthen the wall layers.

Slope stability analysis has been studied extensively, but the behaviour of slope reinforced by geocell is still interesting to explore. This paper aimed to investigate the geocell-reinforced slope made from plastic bottle waste using the 2-D model. The study varies the slope angle, geocell dimension and number of installed layers. This study modelled geocell as a slab that produces flexural and membrane stress. Numerical analyses were also conducted to verify the experimental test results.

\section{Experimental studies}

An experimental test was conducted to obtain the performance of geocell reinforcement against fine sand. Two geocell sizes were used as $5 \mathrm{~cm}$ and $7.5 \mathrm{~cm}$ in height. These sizes were chosen to optimize the use of the plastic bottle. Fig. 1. showed the geocell from intact bottle cut into pieces with two dimensions as $5 \mathrm{~cm}$ height, and 7.5 $\mathrm{cm}$ height because the adequate size of bottle to be used is $15 \mathrm{~cm}$. For $5 \mathrm{~cm}$ height, one bottle can turn into three parts and $7.5 \mathrm{~cm}$ height can turn into two parts. The same in height pieces were then jointed with rivet nails. A schematic view of the plate load test setup is shown in Fig. 2. The external box size is $1100 \mathrm{~mm}$ in length, $1100 \mathrm{~mm}$ in width, $1000 \mathrm{~mm}$ in height and made from iron. Hydraulic jack attached to loading frame and manually operated. The load is distributed uniformly by the steel plate with $120 \mathrm{~mm}$ length, $120 \mathrm{~mm}$ width, $10 \mathrm{~mm}$ thick. In this test, two dial gages are installed to measure soil settlement. The load is applied gradually in constant increments. The experimental results showed that the geocell increase the bearing capacity of the soil. Fig. 3 . shows the load increasing from unreinforced to reinforced soil. A $7.5 \mathrm{~cm}$ height of geocell indicates the highest bearing capacity. The sand used in the experimental test have the parameters such as coefficient of uniformity $\left(C_{u}\right)$ 2.207, coefficient of concavity $\left(C_{c}\right) 1.09$, medium diameter $\left(D_{50}\right) 0.58 \mathrm{~mm}$, maximum diameter $2 \mathrm{~mm}$, specific gravity $\left(G_{s}\right) 2.83$, internal friction $(\varphi) 32$, USCS classification as sand poor graded (SP).

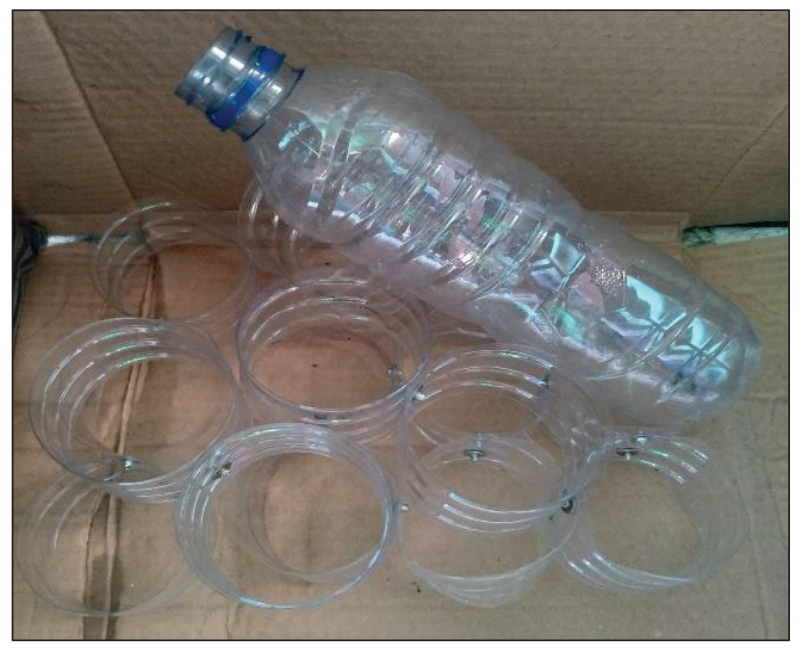

Fig. 1. Geocell materials from the intact bottle and cut into pieces.

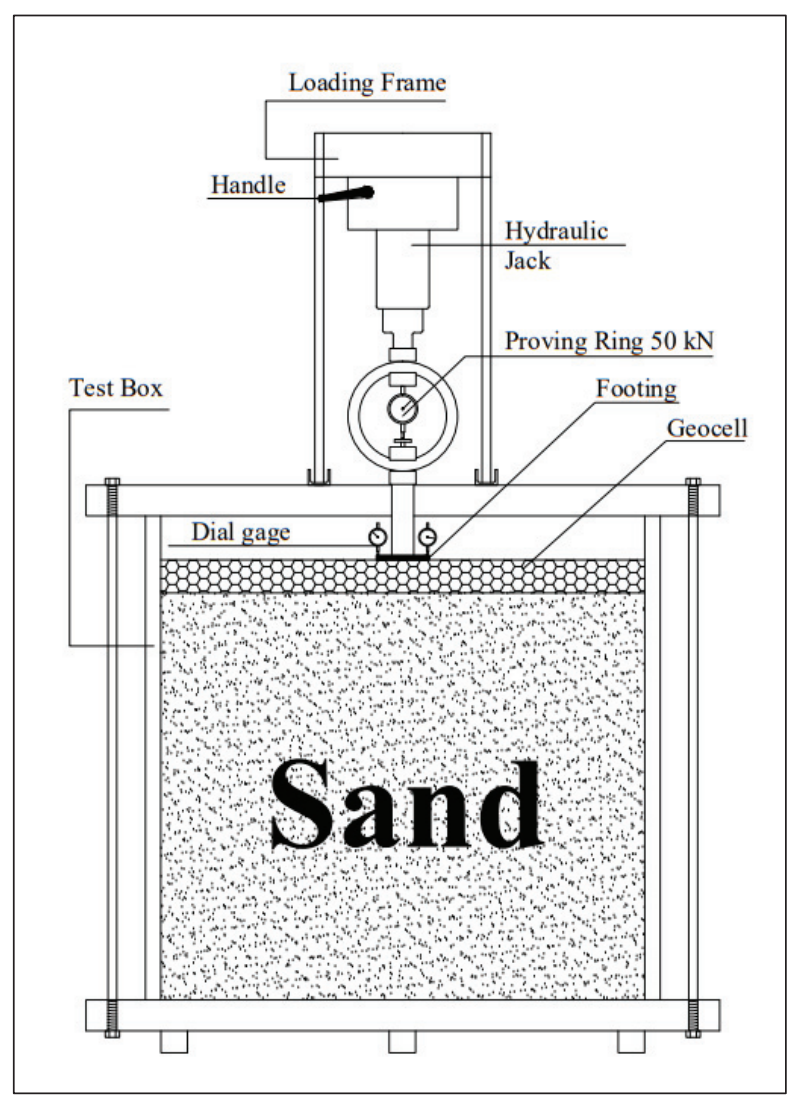

Fig. 2. Schematic view of the test setup. 


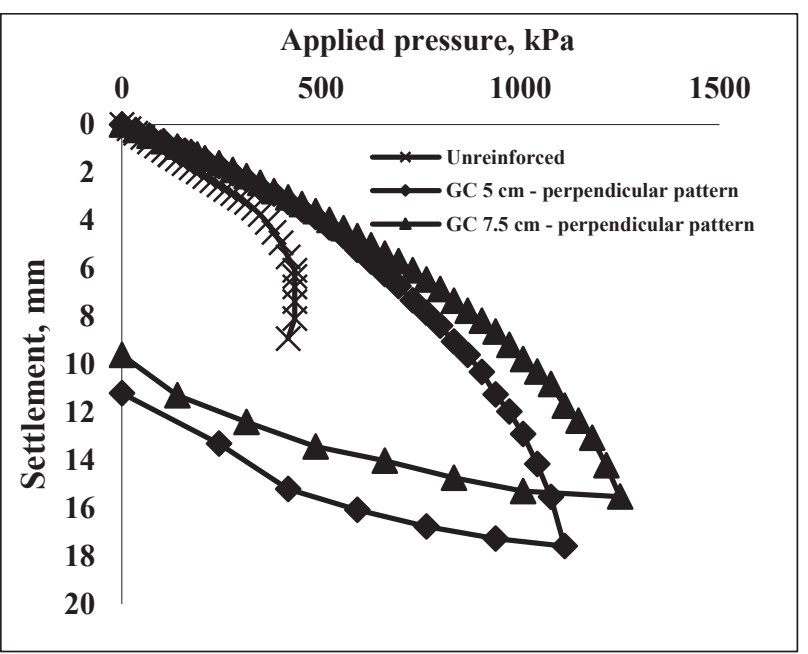

Fig. 3. Applied pressure-settlement.

Schematic view of geocell layer reinforced slope or embankment shown in Fig. 4. By a load of slide mass driven by active earth pressure, the geocell layer gives a tension reaction $(T)$ to hold the slope deformation from its active pressure. This scheme is common to use in slope analysis with geosynthetic reinforcement. The notations $(T),(M)$ and Q, respectively, are the geocell reinforcement tension, bending and shear force of geocell reinforcement. Other notations are load $q(\mathrm{y})$ and $P(y)$ act on super-face and sub-face of geocell. Interface resistance is represented as $\tau_{t}(x)$ and $\tau_{b}(x)$ respectively act at the top and bottom of the geocell layer [9].

\section{Numerical modelling}

2-D modelling using Plaxis 2D V8.6 to perform geocell reinforce slope behaviour. The slope is modelled as plain strain. Plaxis 2D can model geocell reinforcement as a slab that produces stiffness and can spread the load widely. The fact soil eternally behaves non-linear under load. Several levels of sophistication can model the nonlinear stress-strain. Though the soil performs a non-linear behave, it is still able to simplify. Mhor-Coulomb model is well-known to be considered as a simple model. M-C model proposed linear elastic perfectly-plastic with five basic input parameters Young's modulus $(E)$, Poisson's ratio $(v)$, cohesion $(c)$, friction angle $(\varphi)$ angle of dilatancy $(\psi)$. Fig. 5. shows the simplification of non-linear to elastic perfectly-plastic behaviour from standard drained triaxial tests. In reality, on the ground, the soil always behaves non-linearly, resembling the standard drained triaxial tests (Fig. 5 a).

Plaxis2D can perform the non-linear behaviour of soil, but more soil parameters are required. However, the results are more reliable than the simplified model (elastoplastic). The variables that must also evaluate become more. Besides, to simplify analysis with simpler parameters than non-linear. The Mohr-Coulomb model also can be used to perform the elasto-plastic behaviour (Fig. 5 b). The primary difference between the non-linear and the elastic perfectly plastic was the stress-strain curve from different constitutive equations and the number of parameters. In this study, the material model used for soil as an $\mathrm{M}-\mathrm{C}$ model to perform slope reinforcement using geocell in the numerical model. Other sophisticated models can be used in Plaxis, such as Duncan-Chang hyperbolic, Hardening soil, Advanced Mhor-Coulomb model etc.

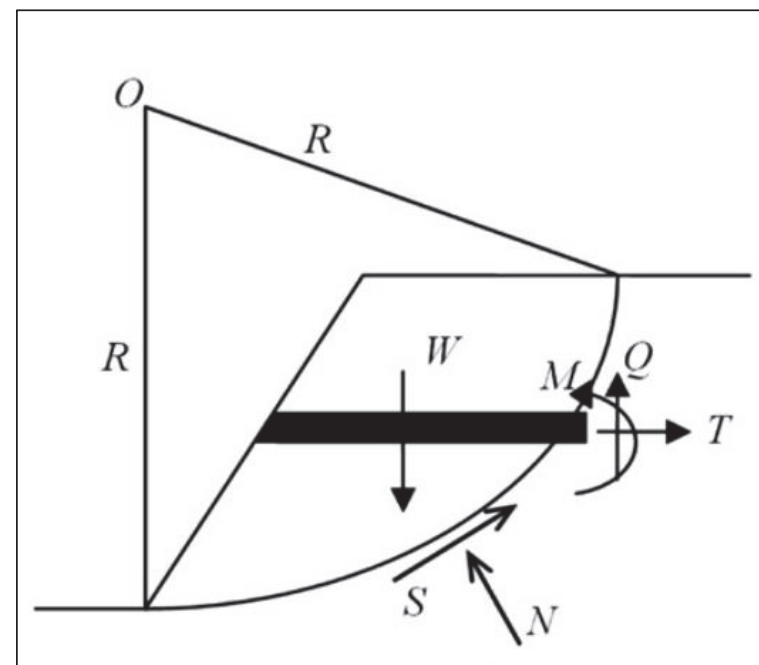

(a)

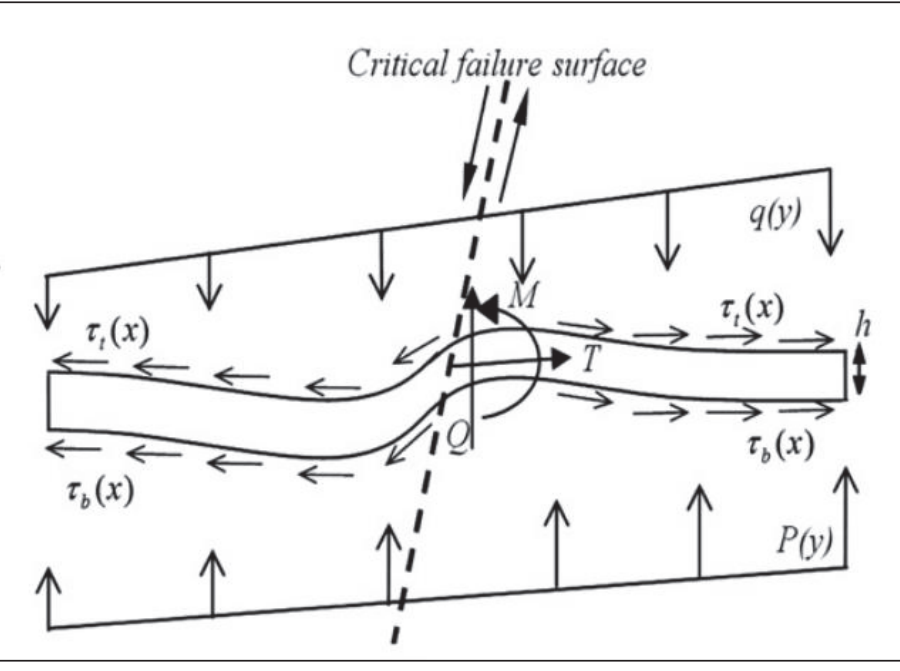

(b)

Fig. 4. Schematic view of geocell reinforced slope; (a) failure mechanism (b) forces act along the geocell reinforcement. [9] 

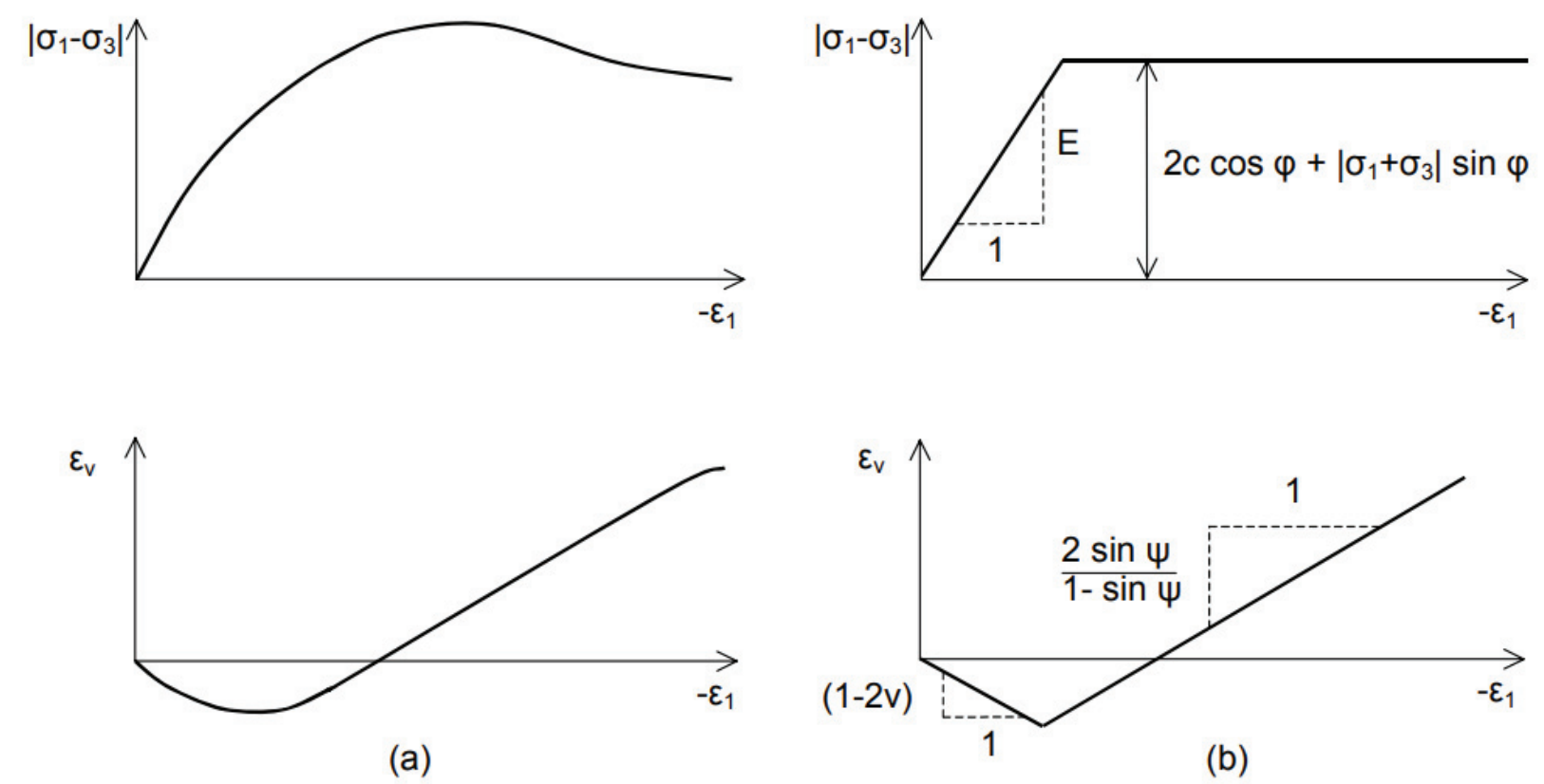

(a)

(b)

Fig. 5. (a) Results from standard drained triaxial tests (b) elasto-plastic model. [12]

Where $\left(\sigma_{1}\right)$ is axial stress, $\left(\sigma_{3}\right)$ is constant confining pressure, $\left(\varepsilon_{1}\right)$ is axial strain, $\left(\varepsilon_{3}\right)$ volumetric strain. Confining pressure can be calculated at-rest earth pressure or $K_{0}$ condition by multiply $K_{0}$ and $\left(\sigma_{1}\right)$.

$$
\sigma_{3}=K_{0} \times \sigma_{1}
$$

where

$$
K_{0}=1-\sin \varphi
$$

\subsection{Estimation of geocell stiffness parameter}

The stiffness parameter of the geocell can be obtained by validating the experimental test result using axisymmetry in Plaxis2D. Axisymmetry modelled half of the box width in Fig. 2. with shape adjustment from square to circle because axisymmetry assumed the box as half-circle. The axisymmetry model was used to estimate the geocell stiffness by several trials.

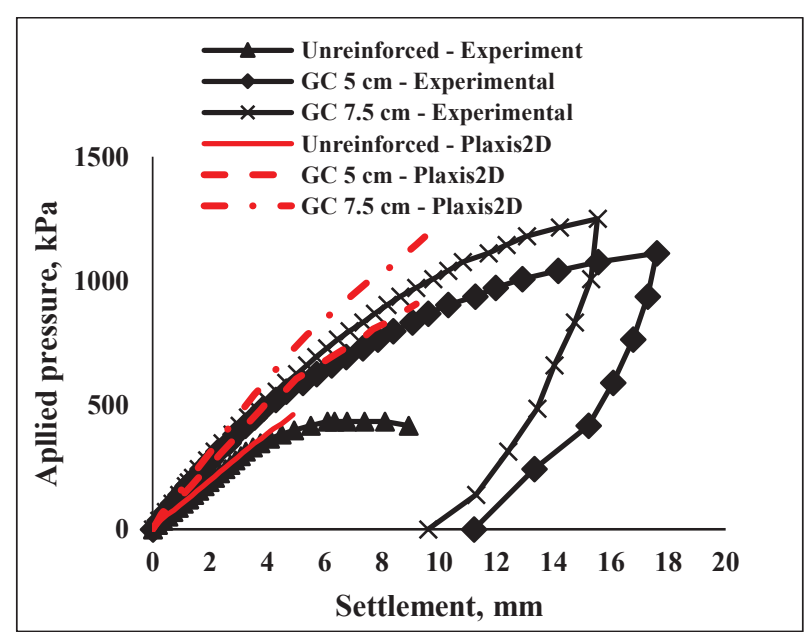

Fig. 6. Comparison between numerical and experimental results.

The geocell is modelled as a plate or slab with EI and $E A$ as the main parameter, bending and axial stiffness, respectively. $E$ is the Young's modulus of geocell, $I$ is the second moment of inertia, and $A$ is the area of geocell. Fig. 6. shows the result between experimental and numerical pressure-settlement in this study.

\subsection{Geometry of slope and reinforcement}

The modelled slope height is 10 meters, with slope variations $(\alpha) 30^{\circ}, 45^{\circ}$ and $60^{\circ}$. Geocell were installed below the slope surface. The top width of slope soil is 15 meters, and the bottom width of slope soil follows the slope. The width of bed soil is 50 meters. Fig. 7. shows the slope geometry used in this model; the typical geometry was proposed by [9]. The detailed geometry of geocell installation are shown in Table 1. $(u)$ is the distance from the top surface to the first layer of geocell, and $(d)$ is the distance between geocell layers.

Table 1. Reinforcement geometry $(\alpha) 30^{\circ}, 45^{\circ}, 60^{\circ}$.

\begin{tabular}{|c|c|c|c|}
\hline State & $\begin{array}{c}\text { Number of } \\
\text { layer }\end{array}$ & $\boldsymbol{u}(\mathbf{m})$ & $\boldsymbol{d}(\mathbf{m})$ \\
\hline Unreinforced & - & - & - \\
\hline Reinforced & 1 & 5 & - \\
\hline & 2 & 2.5 & 5 \\
\hline & 3 & 2 & 3 \\
\hline & 4 & 2 & 2 \\
\hline
\end{tabular}




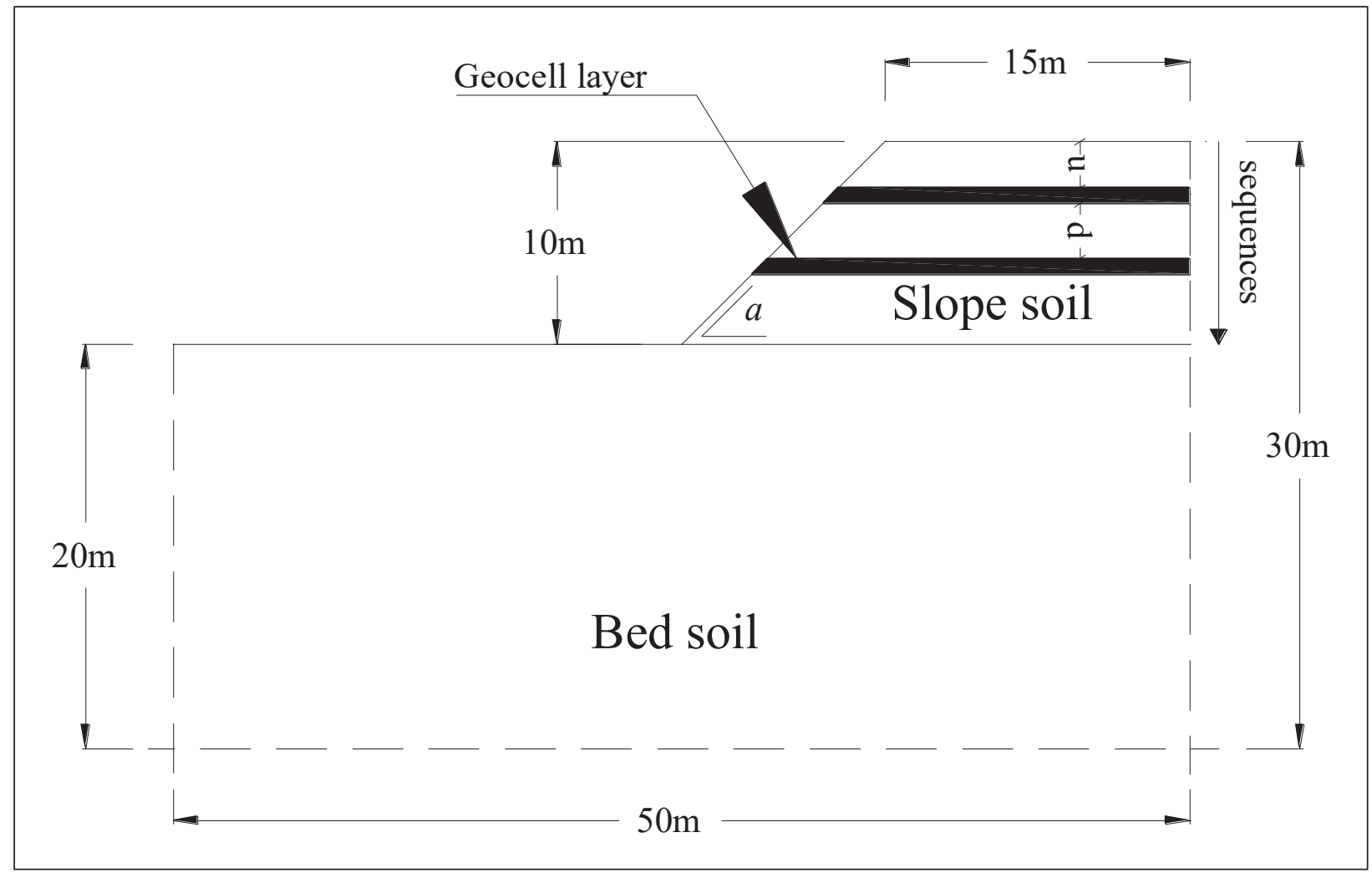

Fig. 7. Slope geometry.

\subsection{Properties material model}

The material model uses the Mohr-Coulomb failure criterion, where the soil material is considered to have an elasto-plastic behaviour or linear path failure. Hence it uses the $\mathrm{M}-\mathrm{C}$ criterion, as mentioned in point 3.1, the geocell stiffness obtained from validating the experimental using axisymmetry in Plaxis2D by several trials. From the validating use of axisymmetry, the Young's modulus of geocell was obtained as in Table 2. The linear function extracted from axisymmetry Plaxis2D is shown in Fig. 8. Soil and geocell properties used are shown in Table 2. The soil interface is input manually as a coefficient in soil properties where geocell are placed. The range of coefficient between $0-1$ is that the value is one, there is no effect of disturbance by the presence of geocell. Besides, if the value is under one, the soil parameter cohesion $(c)$ and friction angle $(\varphi)$ interact along the geocell surfaces are reduced by the coefficient. Groundwater is not used in this study to obtain the geocell effect clearly.

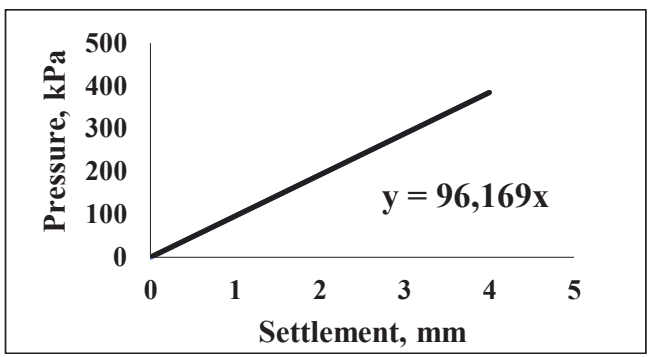

(a)

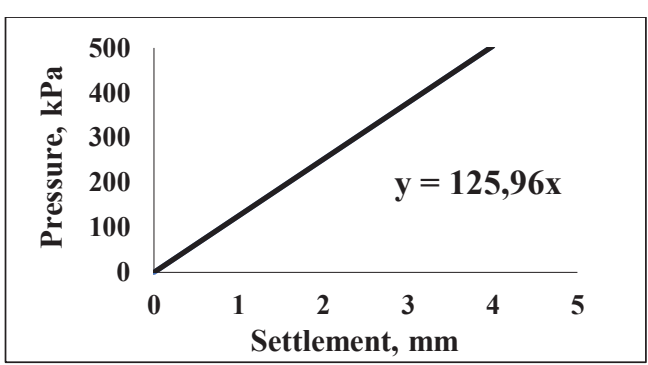

(b)

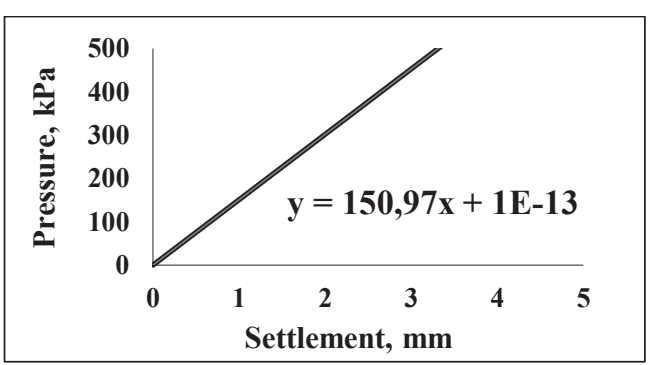

(c)

Fig. 8. pressure-settlement in term elastic condition; (a) unreinforced (b) GC $5 \mathrm{~cm}$ (c) GC $7.5 \mathrm{~cm}$. 
To estimate the initial value of Young's modulus of geocell-soil can be obtained from the equivalent stiffness equation proposed by [13]. This initial value is used to found the closest deal with the trial and error method until the numerical value in Fig. 6 is obtained.

$$
E_{g}=4\left(\sigma_{3}\right)^{0.7}\left(K_{e}+200 M^{0.16}\right)
$$

The modulus parameter above is the horizontal stress at the middle of the geocell layer $\left(\sigma_{3}\right)$, Young's modulus parameter $\left(K_{e}\right)$, secant modulus of geocell material $(M)$. The equation parameter above corresponds to the modulus number of the hyperbolic model proposed by [14]. It should note that the determination of each parameter in this study was also carried out through a series of literature studies.

Table 2. Material properties used in the numerical model.

\begin{tabular}{|c|c|c|}
\hline Soil properties & Bed soil & Slope soil \\
\hline Unit weight $\left(\mathrm{kN} / \mathrm{m}^{3}\right)$ & 17.6 & 17.6 \\
\hline Young's modulus $(\mathrm{kPa})$ & 10000 & 7500 \\
\hline Poisson's ratio & 0.3 & 0.3 \\
\hline \multicolumn{3}{|l|}{ Sandy soil } \\
\hline Internal friction $\left(^{\circ}\right)$ & 31 & 30.5 \\
\hline Cohesion $(\mathrm{kPa})$ & 1 & 1 \\
\hline \multicolumn{3}{|l|}{ Clayey soil } \\
\hline Internal friction $\left(^{\circ}\right)$ & 5 & 5 \\
\hline Cohesion (kPa) & 25 & 25 \\
\hline \multicolumn{3}{|l|}{ Geocell layer properties } \\
\hline Height $(\mathrm{m})$ & 0.05 & 0.075 \\
\hline Diameter of cell $(\mathrm{m})$ & 0.064 & 0.064 \\
\hline Young's modulus $(\mathrm{kPa})$ & 107250 & 206855 \\
\hline $\begin{array}{l}\text { Second moment of area } \\
\qquad\left(\mathrm{m}^{4}\right)\end{array}$ & $1.042 \times 10^{-5}$ & $3.52 \times 10^{-5}$ \\
\hline
\end{tabular}

\section{Results and discussion}

Based on the framework in section 3, this study was conducted to determine the geocell that reinforce a slope, how influential this reinforcement exerts, and the effect of increasing the safety factor. Highly likely that slope angle variations, the two cell dimensions, and the number of layers determines the reinforcement behaviour. Fig. 9. shows both unreinforced and reinforced slope deformation in sandy soil. The unreinforced slope

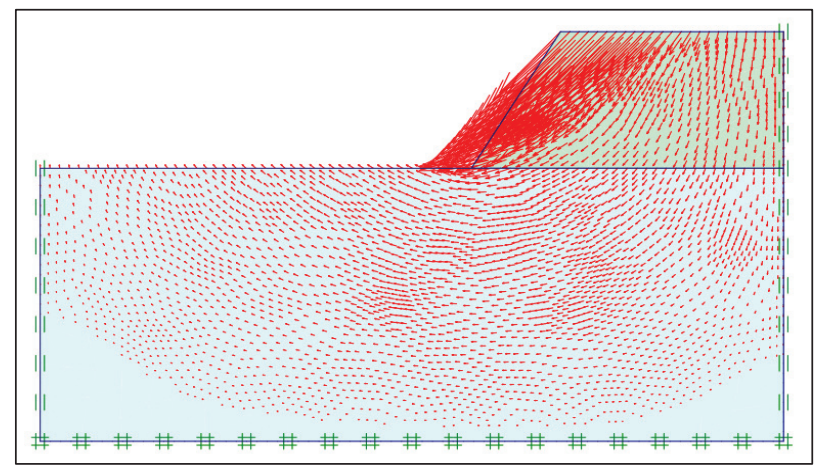

(a) experienced a partial failure at half of the top width slope from the sloping side; the collapsed masses are concentrated only a half body. In contrast with unreinforced, the one layer geocell reinforcement shows a uniform deformation tendency along the sloping plane. This condition represents that geocell can be transferring load in all directions, which strengthens. Fig 10. shows the slope deformation in clayey soil; generally, its behaviour is not much different from sandy soil. In clayey soil, after reinforcement, the total displacement is concentrated to the right side away from the slip surface because clay is very expansive soil. Clay with low cohesion is easy to deform and very compressible. Fig. 11. and Fig. 12. shows the shear strain of the unreinforced and one layer reinforced in sandy soil and clayey soil. From the shear strain, the case of sandy soil shows the deformation is closer to the translation slide, it is represent the nature of sand with flakes collapse or crumble. The clayey soil shows the deformation is more relative to the rotation slide, it is represent the nature of clay with block collapse.

As shown in Fig. 11. and Fig. 12. generally, geocell reinforcement reduces the internal shear strain of the slope. In sandy soil, the maximum shear strain of the unreinforced slope is 24 percent, and the one layer reinforce 17 percent. In clayey soil, the maximum shear strain of the unreinforced slope is 170 percent, and the one layer reinforces 18 percent, which the maximum value occurs at slope foot. The shear strain of unreinforced slope is continuously from top to the slope feet follows the slip surface and as seen over the half of top width are collapses. Different behaviour by the one layer reinforce, the shear strain grade cut off by geocell layer and start again under geocell. As seen, the presence of geocell divided the critical surface and reduced strain. It is represented that geocell absorb the load by collapses mass and transferred along the line, which is more stable. Hence the deformation can be uniformly driven by geocell.

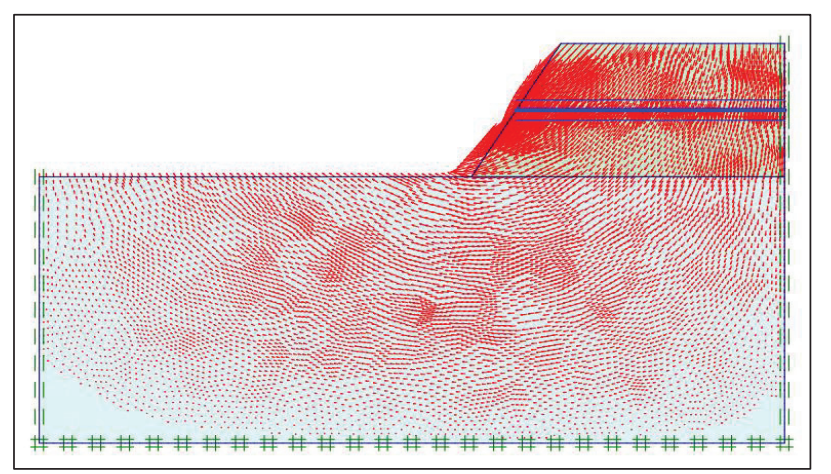

(b)

Fig. 9. Displacement vector of sandy soil at $(\alpha)=60^{\circ}$; (a) unreinforced (b) one layer reinforced. 


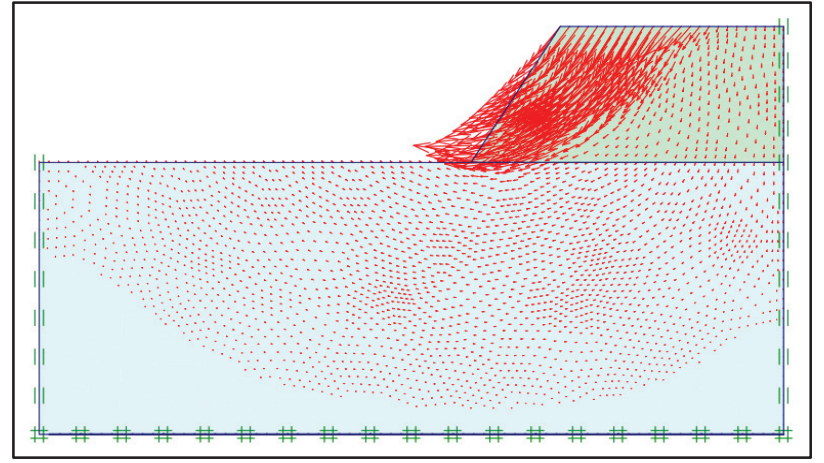

(a)

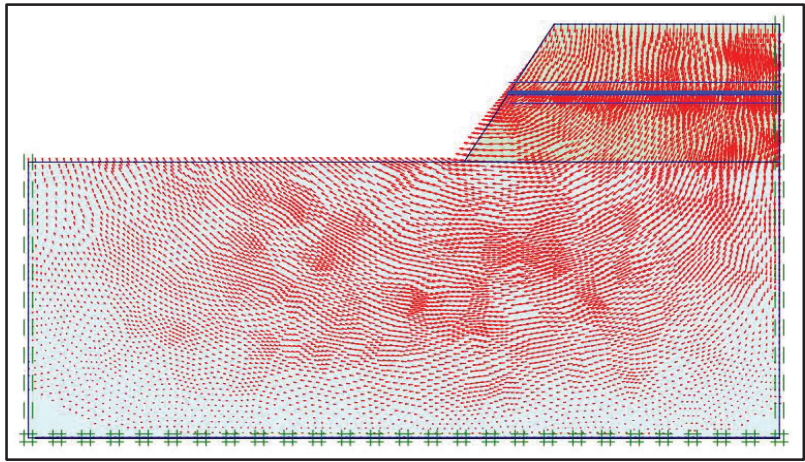

(b)

Fig. 10. Displacement vector of clayey soil at $(\alpha)=60^{\circ}$; (a) unreinforced (b) one layer reinforced.

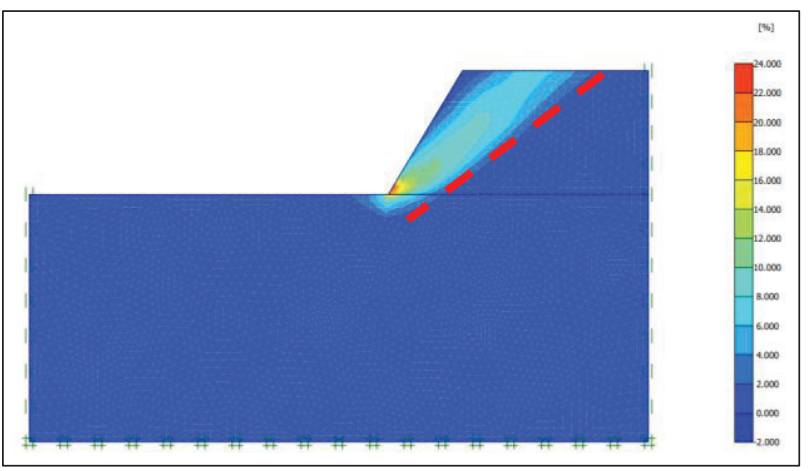

(a)

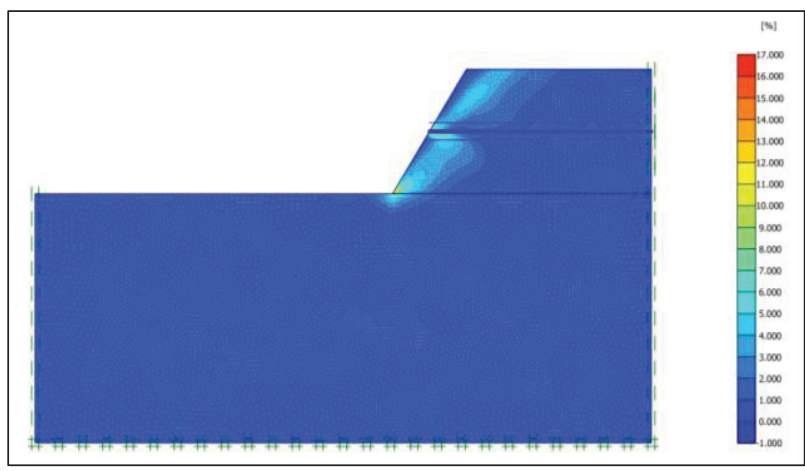

(b)

Fig. 11. Total shear strain of sandy soil at $(\alpha)=60^{\circ}$; (a) unreinforced (b) one layer reinforced.

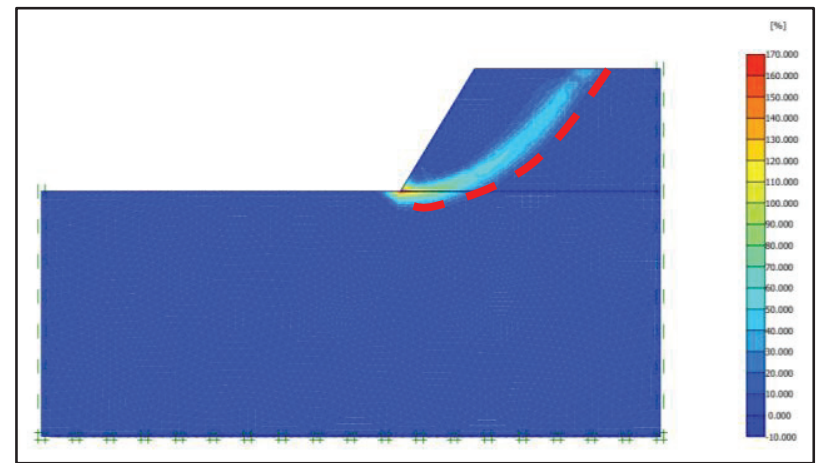

(a)

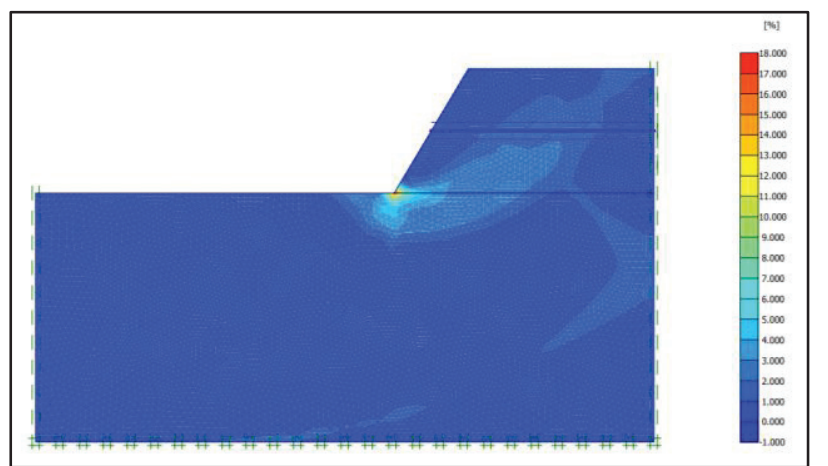

(b)

Fig. 12. Total shear strain of clayey soil at $(\alpha)=60^{\circ}$; (a) unreinforced (b) one layer reinforced.

The reinforcement behaviour can be evaluated by a dimensionless number as an improvement factor $(I F)$, which is the ratio of the safety factor of reinforced to unreinforced.

$$
I F=\frac{F O S_{(\text {reinf orced })}}{F O S_{(\text {unreinf } \text { orced })}}
$$

Where $F O S_{\text {(reinforced) }}$ is the safety factor of reinforced slope and $F O S_{\text {(unreinforced) }}$ is the safety factor of unreinforced. Fig. 13. and Fig. 14. shows improvement factor of each variation modelled both in sandy soil and clayey soil. Reinforcement in sandy soil has a significant effect of increasing the safety factor. Unlike clayey soil, the reinforcement effect is not so substantial because clay is compressible, and the vertical deformation of clay with low strength is significant. The more layers installed, the higher $(I F)$ are obtained based on the number of layers. By the height of the cell, the $7.5 \mathrm{~cm}$ gave a higher safety factor. The significant differences in the improvement factor are indicated by slope angle variation. The $60^{\circ}$ produces the highest value of $(I F)$. It is because the geocell layer intersects the critical slip surface, where the active soil mass is highest on the $60^{\circ}$ slope. The improvement factor $(I F)$ of one layer $\mathrm{GC} 5 \mathrm{~cm}$ reinforcement in sandy soil with slopes of $30^{\circ}, 45^{\circ}$ and $60^{\circ}$ are respectively $1.05,1.07$ and 1.35 , while the GC 7.5 $\mathrm{cm}$ with slopes of $30^{\circ}, 45^{\circ}$ and $60^{\circ}$ respectively $1.11,1.16$ and 1.34. The improvement factor (IF) of one layer GC 5 $\mathrm{cm}$ reinforcement in clayey soil with slopes of $30^{\circ}, 45^{\circ}$ and $60^{\circ}$ are respectively $1.08,1.04$ and 1.02 , while the GC $7.5 \mathrm{~cm}$ with slopes of $30^{\circ}, 45^{\circ}$ and $60^{\circ}$ respectively 1.03 , 1.01 and 1.01 . 


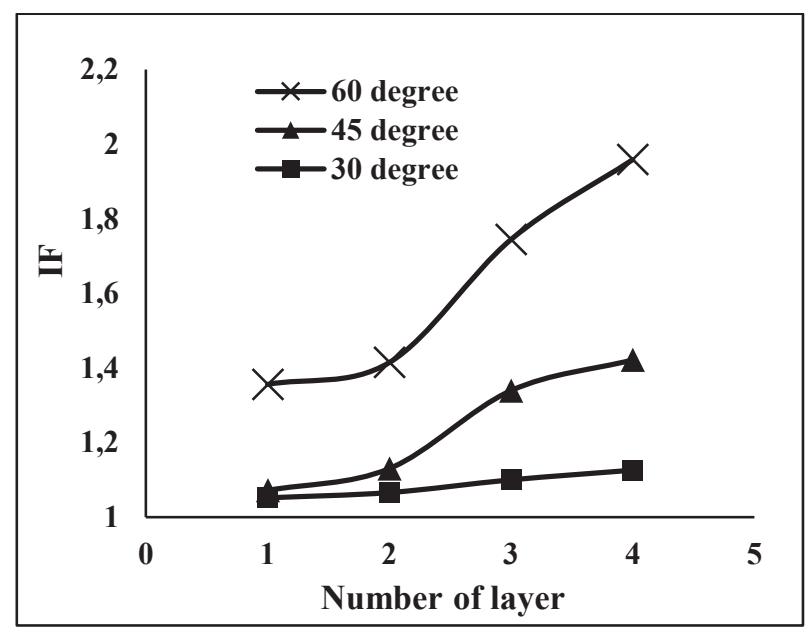

(a)

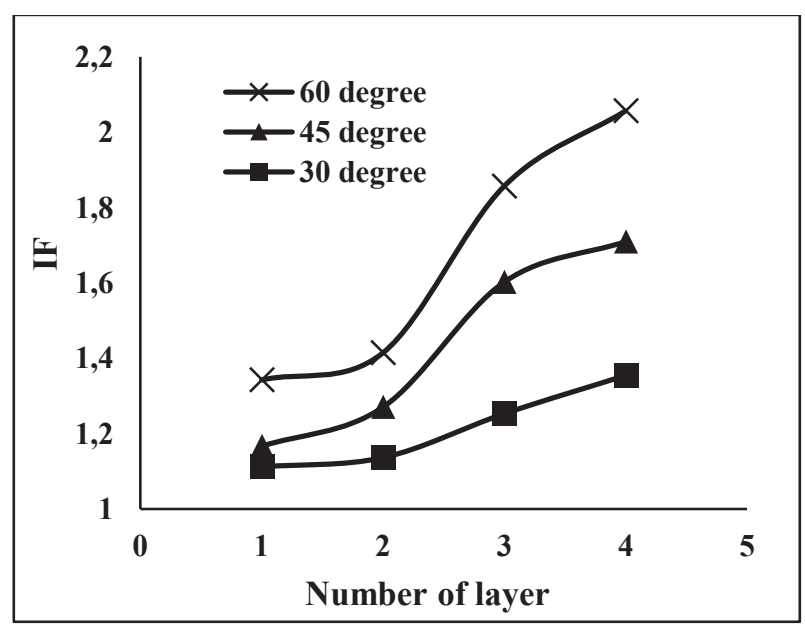

(b)

Fig. 13. Improvement factor of the geocell reinforcement in sandy soil with different heights of; (a) GC $5 \mathrm{~cm}$ (b) GC $7.5 \mathrm{~cm}$.

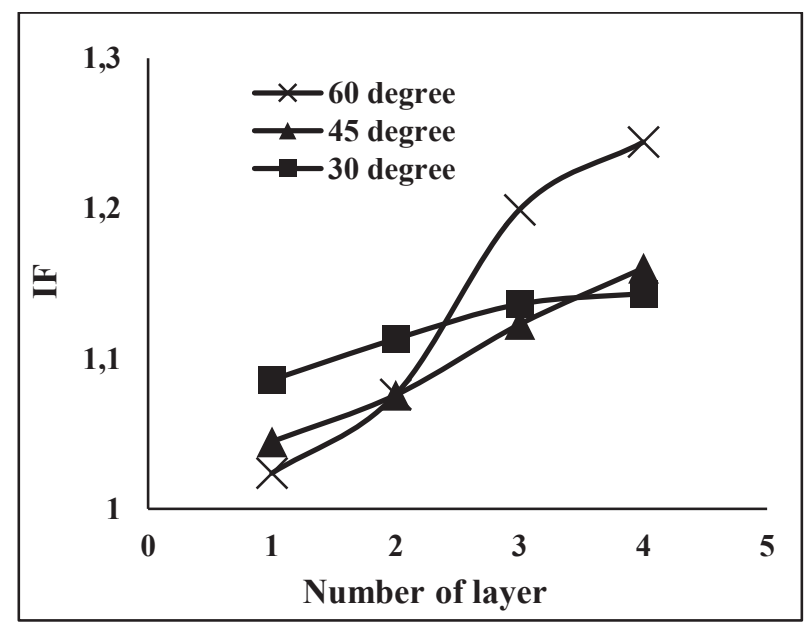

(a)

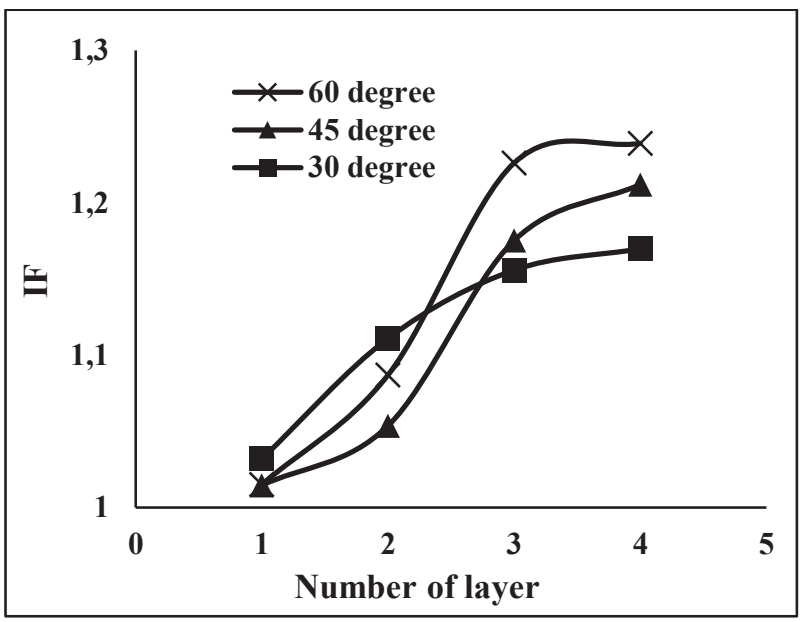

(b)

Fig. 14. Improvement factor of the geocell reinforcement in clayey soil with different heights of; (a) GC $5 \mathrm{~cm}$ (b) $7.5 \mathrm{~cm}$.

The numerical analysis also obtained the axial force acting on each geocell layer. The numerical results show that the maximum force is different in each typical geometry and the number of layers used. The maximum axial forces of one layer GC $5 \mathrm{~cm}$ in sandy soil with slopes variations of $30^{\circ}, 45^{\circ}$ and $60^{\circ}$ are respectively, 13.91 $\mathrm{kN} / \mathrm{m}, 50.31 \mathrm{kN} / \mathrm{m}$ and $82.4 \mathrm{kN} / \mathrm{m}$. Then the $7.5 \mathrm{~cm}$ with slopes variations of $30^{\circ}, 45^{\circ}$ and $60^{\circ}$ respectively, 34.65 $\mathrm{kN} / \mathrm{m}, 61.47 \mathrm{kN} / \mathrm{m}$ and $103.69 \mathrm{kN} / \mathrm{m}$. The maximum axial forces in clayey soil with one layer $5 \mathrm{~cm}$ reinforcement with slopes of $30^{\circ}, 45^{\circ}$ and $60^{\circ}$ respectively, $27.12 \mathrm{kN} / \mathrm{m}$, $43.12 \mathrm{kN} / \mathrm{m}$ and $33.20 \mathrm{kN} / \mathrm{m}$. Then the $7.5 \mathrm{~cm}$ with slopes of $30^{\circ}, 45^{\circ}$ and $60^{\circ}$ respectively, $67.17 \mathrm{kN} / \mathrm{m}, 81.75 \mathrm{kN} / \mathrm{m}$ and $126.79 \mathrm{kN} / \mathrm{m}$.

As shown in Fig. 15. the $5 \mathrm{~cm}$ geocell in sandy soil has a smaller axial force than $7.5 \mathrm{~cm}$ because of the different thicknesses. The $7.5 \mathrm{~cm}$ height produce a higher Axial stiffness than $5 \mathrm{~cm}$ height, so it also absorbs a higher axial force than $5 \mathrm{~cm}$ height. Hence the axial forces are smaller, almost the same with the improvement factor even though the differences are slight in the $60^{\circ}$ slope but significant enough at $30^{\circ}$ and $45^{\circ}$ slope. Unlike the clayey soil, there are almost no axial forces differences by the variated slope angle, Fig. 16. shows the axial forces are overlaps between the variation in angle. The very contrasting difference of axial force between the $5 \mathrm{~cm}$ and $7.5 \mathrm{~cm}$ height because the $7.5 \mathrm{~cm}$ height produce a higher axial stiffness so it can absorb a higher force than $5 \mathrm{~cm}$ height. Almost all the $7.5 \mathrm{~cm}$ height geocell are in the bottom layer in clayey soil have the highest axial forces above one hundred kilonewtons. It denotes that the clayey soil with the above parameters in Table 2. has a large enough deformation and poor safety factor. Actually, the internal force in geocell like axial, shear and moment depend on many factors. The type of geocell, material, the geometry of slope and placement, how many layers are placed, and the soil strength parameters. In this study, the shear force and bending moment act on geocell in every number of layers, and variated angles are very small. So, the shear force and bending moment can be ignored. 


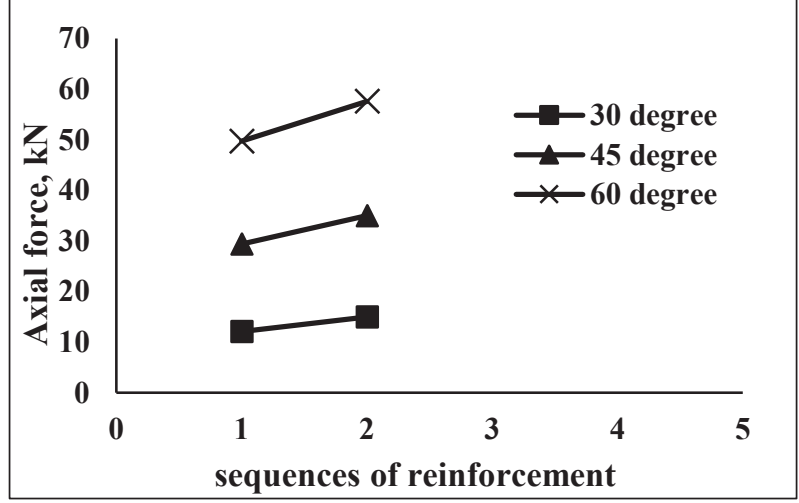

(a) 2 layers

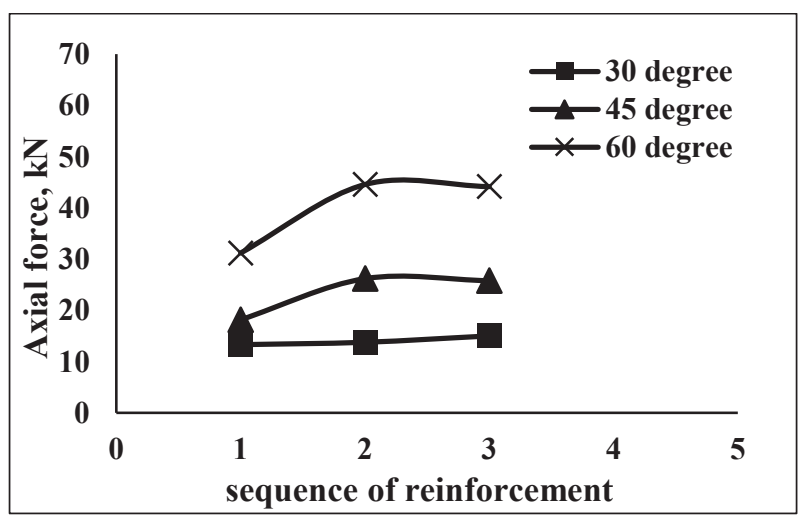

(b) 3 layers

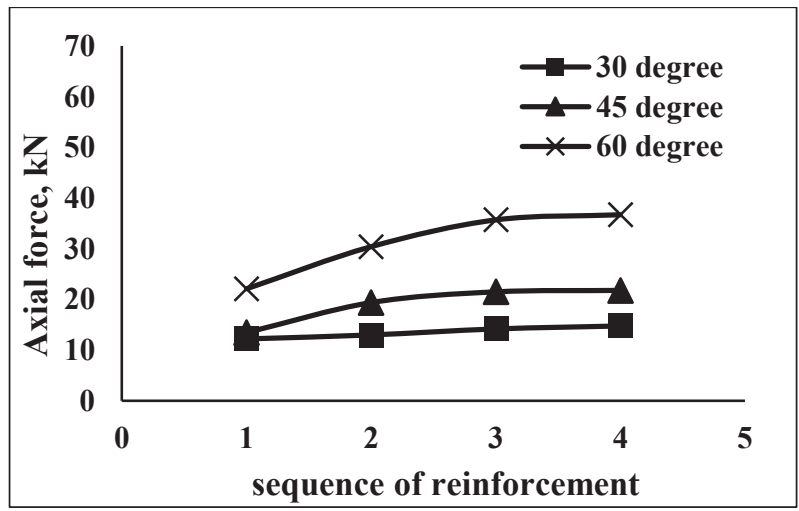

(c) 4 layers

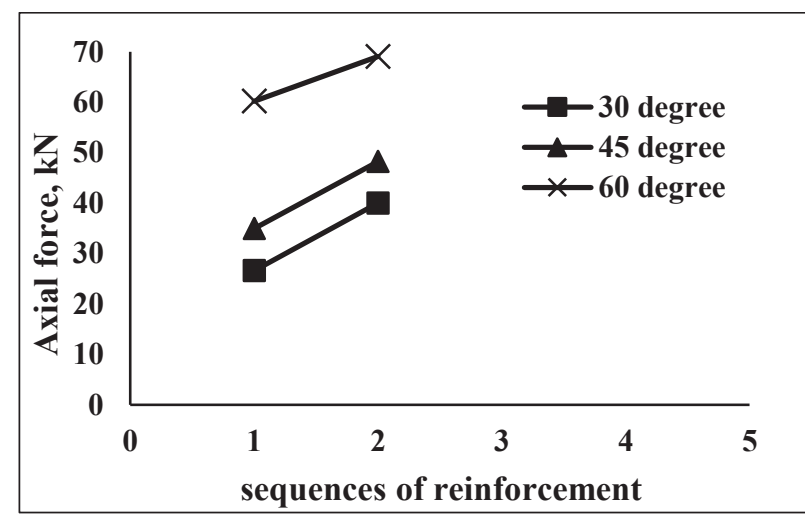

(d) 2 layers

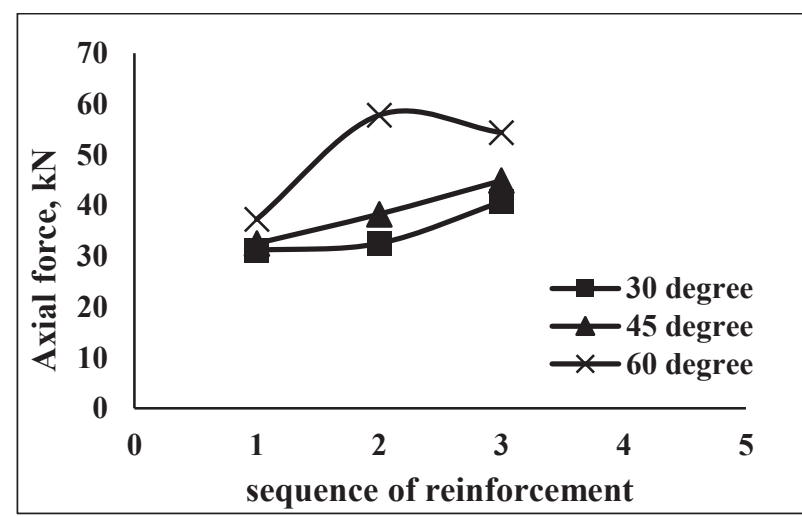

(e) 3 layers

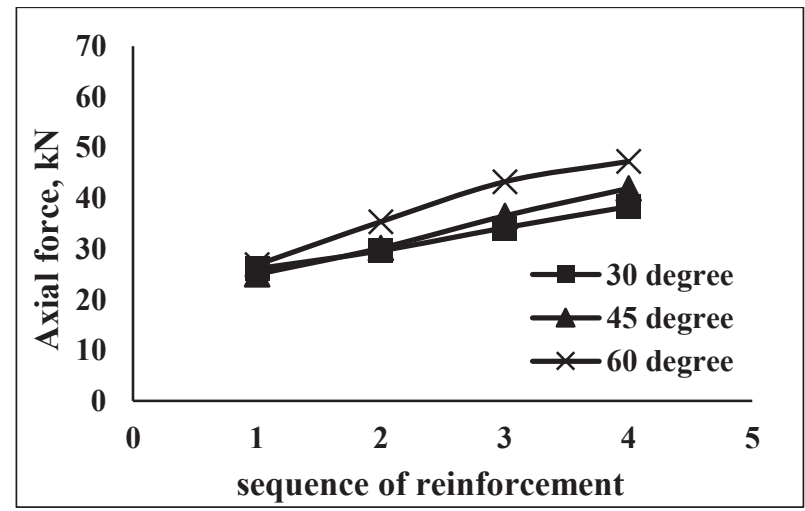

(f) 4 layers

Fig. 15. Maximum axial forces of the geocell in sandy soil with; (a b c) $5 \mathrm{~cm}$ height (d e f) $7.5 \mathrm{~cm}$ height.

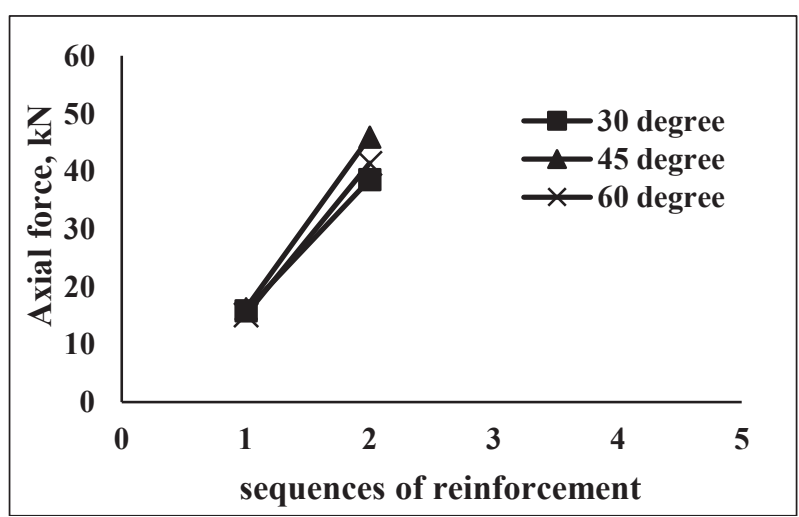

(a) 2 layers

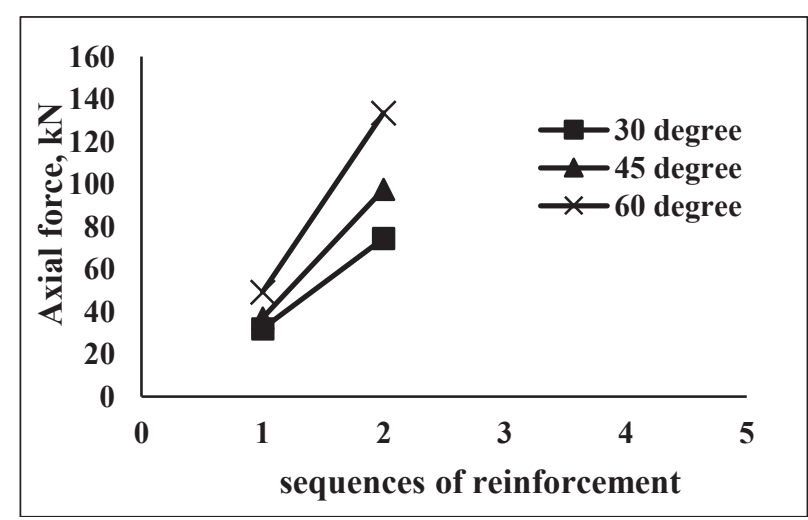

(d) 2 layers 


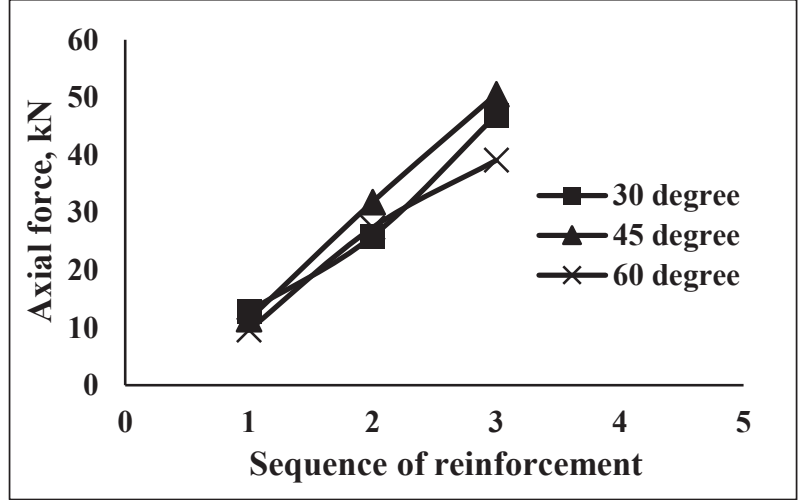

(b) 3 layers

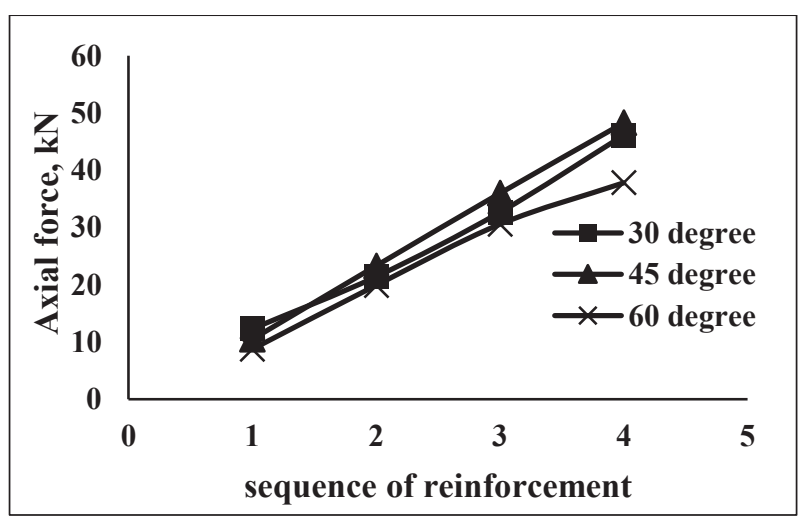

(c) 4 layers

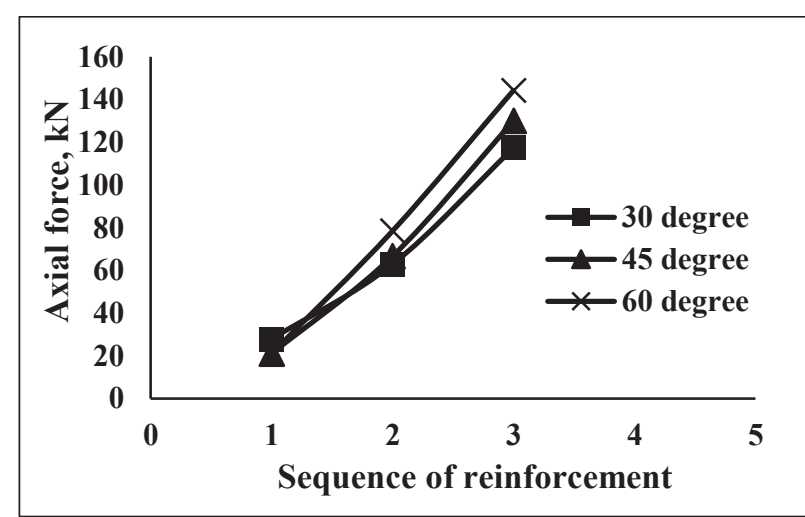

(e) 3 layers

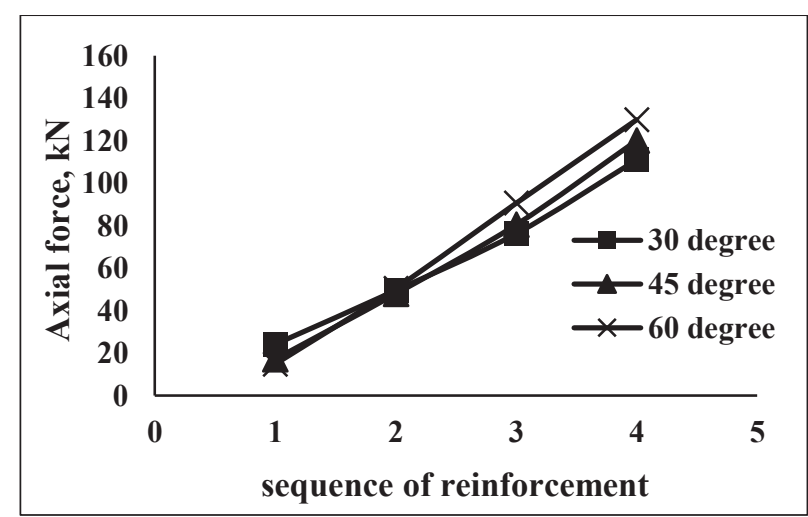

(f) 4 layers

Fig. 16. Maximum axial forces of the geocell in clayey soil with; (a b c) $5 \mathrm{~cm}$ height (d e f) $7.5 \mathrm{~cm}$ height.

\section{Conclusion}

This paper presents numerical modelling of geocell reinforced slope modelled as a slab. The purpose of this paper is to find out how effectively waste plastic bottles can be used as geocells in slope reinforcement. The experimental test showed bottled waste geocells increase soil stiffness by providing additional lateral confining, Increase bearing capacity. Generally, the geocell reinforce slope can improve the safety factor.

In sandy soil, the result shows that geocell has a significant effect on the improvement factor. The number of layers installed affects the improvement factor $(I F)$ value; the more layers established; the higher improvement factor is obtained. A significant effect is seen on the $60^{\circ}$ slope as seen with the highest improvement factor. The effect of geocell reinforcement on the $30^{\circ}$ slope is not significant because the $30^{\circ}$ is relatively stable by the angle of internal friction of $30.5^{\circ}$.

Unlike the sandy soil, in the clayey soil case, the effect of geocell reinforcement is not very significant. The improvement factor shows that geocell gives a small improvement to safety factor; although the axial force act on geocell is very high, the total deformation of the slope is still high even with the presence of the geocell. It means the clayey soil need a more stiff material or a larger dimension of geocell to restrain deformation and can equalizing the improvement factor with the sandy soil.
The shear strain of unreinforced slope in clayey soil is very high than sandy soil. The two results above between sandy soil and clayey soil show that geocell is more effective to use in sandy soil than in clayey soil. Various results are also obtained by varying the slope, the number of reinforcement layers and the geocell height. Those variations above determine the improvement factor $(I F)$.

\section{List of symbols}

$A \quad$ area of geocell $\left(\mathrm{m}^{2}\right)$

$C_{u} \quad$ coefficient of uniformity

$C_{c} \quad$ coefficient of concavity

c cohesion of soil $(\mathrm{kPa})$

$D_{50}$ medium diameter ( $\left.\mathrm{mm}\right)$

$d \quad$ distance between geocell layers (m)

$E \quad$ Young's modulus $(\mathrm{kPa})$

$E_{g}$ equivalent stiffness of geocell reinforced soil $(\mathrm{kPa})$

FOS (reinforced) safety factor of reinforced soil

FOS (unreinforced) safety factor of unreinforced soil

$G_{S} \quad$ specific gravity

I second moment of inertia $\left(\mathrm{m}^{4}\right)$

IF improvement factor

$K_{0} \quad$ at-rest lateral earth pressure coefficient

$K_{e} \quad$ Young's modulus parameter of the unreinforced soil $(\mathrm{kPa})$

$M \quad$ secant modulus of geocell material $(\mathrm{kN} / \mathrm{m})$

$P(y)$ subgrade reaction at bottom of geocell 
$Q \quad$ shear force of geocell reinforcement

$q(y)$ uniform load act on super-face of geocell

$T$ tension force of geocell reinforcement

$u$ distance from the top ground surface to the first

layer of geocell $(\mathrm{m})$

$\alpha \quad$ slope angle $\left({ }^{\circ}\right)$

$\varphi \quad$ friction angle of the soil $\left({ }^{\circ}\right)$

$\sigma_{1} \quad$ axial stress $(\mathrm{kPa})$

$\sigma_{3} \quad$ confining pressure $(\mathrm{kPa})$

$\tau_{b}(x)$ interface resistance at bottom of geocell

$\tau_{t}(x)$ interface resistance at top of geocell

$\varepsilon_{1} \quad$ axial strain

$\varepsilon_{3} \quad$ volumetric strain

$v \quad$ Poisson's ratio of soil

$\psi \quad$ angle of dilatancy $\left(^{\circ}\right)$

\section{References}

1. United States Environmental Agency, Environmental factoids. Available from: www.thebalancesmb.com., 2021. The decomposition of waste on landfills. https://www.thebalancesmb.com/how-long-does-ittake-garbage-to-decompose-2878033. [accessed 19 February 2021]

2. T.S. Ingold, The geotextiles and geomembranes manual (Elsevier Science Publishers LTD, 1994)

3. W.F. Van Impe, Soil Improvement Techniques and Their Evolution (Taylor \& Francis, 1989).

4. X.M. Yang, J. Han, R.L. Parsons, D. Leshchinsky, Springer-Verlag, Front. Archit. Civ. Eng. China, 4 (2), 233-240 (2010)

5. A. Hedge, T.G. Sitharam, Geotextiles and Geomembranes, 43, 171-181 (2015)

6. R. J. Bathrust, M.A. Knight, Comput. Geotech. 22 (3/4), 205-219 (1993)

7. G.M. Latha, A. Somwanshi, Geotext. Geomembr. 27, 409-422 (2009)

8. A. Hedge, T.G. Sitharam, Int. J. Geotech. Eng. 7 (4), 347-354 (2013)

9. I. Mehdipour, M. Ghazavi, R.Z. Moayed, Geotext. Geomembr. 37, 23-24 (2013)

10. G.M. Latha, K. Rajagopal, Canadian Geotechnical Journal 44 (8), 917-927 (2007)

11. H.I. Ling, D. Leshchinsky, J.P Wang, Y. Mohri, A. Rosen, Journal of Geotechnical and Geoenvironmental Engineering, ASCE 135 (4), 515524 (2009)

12. Plaxis, Plaxis $2 \mathrm{D}$ V8 manual reference (2002)

13. K. Rajagopal, N.R. Krishnaswamy, G.M. Latha, Computer Methods and Advances in Geomechanics, 1251-1254, Balkema (2001)

14. J.M Duncan, C.Y Chang, Non-linear analysis of stress and strain in soils, Journal of the Soil Mechanics and Foundations Division, ASCE 96, 1629-1653 (1970) 